\title{
Interventions performed by the clinical pharmacist in the emergency department
}

\author{
Intervenções realizadas pelo farmacêutico clínico na unidade de primeiro atendimento
}

\author{
Talita Muniz Maloni Miranda ${ }^{1}$, Sandra Petriccione $^{1}$, Fabio Teixeira Ferracini $^{1}$, Wladimir Mendes Borges Filho ${ }^{1}$
}

\begin{abstract}
Objective: To demonstrate the role and importance of the clinical pharmacist in the Emergency Department by means of identification, classification, and assessment of the number of interventions performed by this professional. Methods: This was a retrospective study conducted during the period of January $1^{\text {st }}, 2010$ to December $31^{\text {st }}, 2010$, at the Morumbi Emergency Department of Hospital Israelita Albert Einstein. The interventions were performed by the clinical pharmacists by means of his/her role along with the interdisciplinary team and active search in clinical charts, with daily analysis of medical prescriptions during the period of eight hours (10:00 to 19:00) from Monday to Friday. Results: A total of 3,542 medical prescriptions were written and there were 1,238 interventions. Classifications and quantities of interventions were as follows: administration route: $105(8.48 \%)$; frequency: $73(5.89 \%)$; dosage: 431 (35\%); renal function: $14(1.13 \%)$; compatibility: 50 (4\%); dilution: 121 (9.77\%); legibility: 39 (3.15\%); pharmacovigilance: $7(0.56 \%)$; adverse reaction to medications: $7(0.56 \%)$; allergy: 35 (2.82\%); infusion time: 76 (6.13\%); indication: 52 (4.20\%); medication reconciliation: $2(0.16 \%)$; enteral medication administration: $38(3 \%)$; scheduling: 7 (0.56\%); specific anticoagulant protocol: $44(3.55 \%)$; specific hypoglycemic agent protocol: 42 (3.99\%). Conclusion: The study allowed the demonstration of the importance of the clinical pharmacist active in the Emergency Department. By the classification and by the number of interventions carried out, it was possible to observe that the Clinical Pharmacy Service had a great impact on the increased safety for the patient and prevention of adverse events.
\end{abstract}

Keywords: Pharmacists/utilization; Emergency medical services

\section{RESUMO}

Objetivo: Demonstrar a atuação e a importância do farmacêutico clínico na Unidade de Primeiro Atendimento por meio da identificação, classificação e do levantamento do número de intervenções realizadas pelo farmacêutico clínico. Métodos: Foi realizado um estudo retrospectivo no período de $1^{\circ}$ de janeiro de 2010 a 31 de dezembro de 2010, na Unidade de Primeiro Atendimento Morumbi do Hospital Israelita Albert Einstein. As intervenções foram realizadas pelo farmacêutico clínico por meio da atuação junto à equipe interdisciplinar e busca ativa nos prontuários, com a análise diária da prescrição médica no período de oito horas $(10 \mathrm{~h} 00 \mathrm{e}$ 19h00) de segunda à sexta-feira. Resultados: Foi avaliado 0 total de 3.542 prescrições médicas e ocorreram 1.238 intervenções. As classificações e as quantidades das intervenções foram: via de administração: 105 (8,48\%); frequência: 73 (5,89\%); dose: 431 (35\%); função renal: $14(1,13 \%)$; compatibilidade: 50 (4\%); diluição: $121(9,77 \%)$; legibilidade: $39(3,15 \%)$; farmacovigilância: $7(0,56 \%)$; reação adversa a medicamentos: $7(0,56 \%)$; alergia: $35(2,82 \%)$; tempo de infusão: $76(6,13 \%)$; indicação: $52(4,20 \%)$; reconciliação medicamentosa: $2(0,16 \%)$; medicamentos via sonda: $38(3 \%)$; aprazamento: $7(0,56 \%)$; protocolo específico de anticoagulantes: 44 (3,55\%); protocolo específico de hipoglicemiantes: 42 (3,99\%). Conclusão: 0 estudo permitiu demonstrar a importância do farmacêutico clínico atuando na Unidade de Primeiro Atendimento. Pela classificação e pelo número das intervenções realizadas, foi possível observar que o Serviço de Farmácia Clínica teve grande impacto no aumento da segurança ao paciente e prevenção de eventos adversos.

Descritores: Farmacêuticos/utilização; Serviços médicos de emergência

\section{INTRODUCTION}

Emergency situations may occur in all sectors of the hospital, but their main location is the Emergency Department, which is one of the entrance doors for patients. This sector treats at the tertiary level of healthcare and is designed to receive people in crisis situations, with or without imminent risk of death, who need emergency treatment ${ }^{(1)}$.

\footnotetext{
Study carried out at Hospital Israelita Albert Einstein - HIAE, São Paulo (SP), Brazil.

1 Hospital Israelita Albert Einstein - HIAE, São Paulo (SP), Brazil.

Corresponding author: Talita Muniz Maloni Miranda - Avenida Albert Einstein, 627 - Morumbi - Zip code: 05651-901 - São Paulo (SP), Brazil - Phone: (11) 2151-2248 - E-mail: talitamm@einstein.br

Received on: Apr 29, 2011 - Accepted on: Sep 20, 2011
}

Conflict of interest: None 
Although a limited number of pharmacists are active in Emergency Medicine, the Emergency Clinical Pharmacy Service has been documented since 1970(2), although few hospitals have a clinical pharmacist who is active in the Emergency Department (ED); in the United States, only 1 to $3 \%$ of hospitals offer this service $^{(3)}$.

Few articles describe the role or effect of the clinical pharmacist at the Emergency Department. Such a lack of data has led to a grand debate as to the need to allocate resources for the Services of Clinical Pharmacy in the ED, and as to how to implant such services in order to promote quality and safety in the Emergency Department $^{(4)}$.

Recently, some studies have demonstrated that pharmaceutical interventions in the ED may generate reduced costs, and that the clinical pharmacist may increase the quality of care to the patient and safety as to drug therapy; he/she can also identify and prevent errors in medication, since the greatest frequency of avoidable events in hospitals occur in the $\mathrm{ED}^{(5-7)}$. Errors in medication in the ED may be reduced significantly when the pharmacist revises the prescription, and it was also noted that almost all recommendations made by the pharmacist were accepted by the other healthcare professionals $^{(8)}$.

Analysis of the medical prescription is one of the main activities of the clinical pharmacist in an ED, since with clinical knowledge of the patient it is possible to analyze the medical prescription and perform pharmaceutical intervention in cases of:

- medications that are not on the hospital's standardized list of drugs; the suggestion is made to the physician for substitution of another drug that is on the formulary of the hospital, and when this is not possible, the medication is bought.

- inexistent pharmaceutical formulation or a formulation inappropriate for administration;

- unsuitable administration route for the administration prescribed;

- inexistent dosage and/or a dosage greater or smaller than the usually prescribed dosage;

- unsuitable frequency of administration of the drug;

- unsuitable mode of administration relative to that described in literature;

- unsuitable or incompatible diluent for use with the prescribed medication, diluents and packaging;

- incompatibility among medications;

- prescription of medications with the same pharmacologic action;

- illegible medications or those with incomplete descriptions; other nonconformities that need to be clarified by the medical team.

Besides pharmaceutical interventions, other benefits related to the role of the clinical pharmacist in the ED include participation along with the interdisciplinary team, interaction with the patient in order to obtain a history of medications habitually used, provision of information about medications, including specific information on dosage adjustments of medications for renal insufficiency, age, or weight, toxicological and pharmacological information, instructions as to administration and substitution of medications, or any other questions regarding the use of the $\operatorname{drugs}^{\left({ }^{(9)}\right.}$.

Pharmaceutical interventions are performed in order to obtain correct and safe use of the medications.

\section{OBJECTIVE}

The objective of this study was to demonstrate the role and importance of the clinical pharmacist in the ED by identification, classification, and investigation of the number of interventions performed by the clinical pharmacist.

\section{METHODS}

A retrospective study was conducted during the period of January $1^{\text {st }}, 2010$ to December $31^{\text {st }}, 2010$, at the Morumbi ED of Hospital Israelita Albert Einstein (HIAE). This unit sees adult and pediatric patients, daily treating approximately 400 cases in the clinical areas of obstetrics, clinical, surgical, psychiatric, pediatric, and trauma.

The Pharmacy Service initiated in the ED in March 2009. Interventions were performed by the clinical pharmacist by means of cooperation with the interdisciplinary team through an active search in clinical charts, with analysis of the daily medical prescription over an 8-hour period (10:00 - 19:00), from monday to friday. Interventions were referred to the clinical pharmacy coordinator daily by e-mail at the time of shift changing, and it was possible to acquire data using these records.

According to the analysis of the medical prescription, the clinical pharmacist made interventions as to the pertinence of the medication, its indication, dose, frequency, and route of administration (oral, tube, intravenous and intramuscular). For medications given by tubes, there was evaluation of a possible substitution when tablets or capsules prescribed are not to be broken, crushed or opened, and substitution of tablets or capsules with drops or oral suspensions. Medical prescription 
evaluation for pediatric and neonatal patients was made as to dosage related to weight, adjustment of dosage or frequency for antimicrobials prescribed in cases of renal failure, therapeutic duplicity, real or potential allergies or sensitivities, drug-drug interactions, legibility, scheduling, compatibility, medication reconciliation, dilution, and time of infusion. Patients receiving anticoagulants and hypoglycemic agents were followed by means of specific protocols, in which the pharmacist assessed the prescription of intravenous heparin, warfarin, regular insulin and lispro insulin.

Nonconformities verified in prescriptions were previously consulted in specific literature. By means of technical consultation, the pharmacist made contact with the physician or care team for the resolution of the irregularity found and recorded on the clinical chart (prescription and multi-professional clinical progress) the change made or the position taken.

\section{RESULTS}

During the period from January $1^{\text {st }}$ to December $31^{\text {st }}$, a total of 3,542 medical prescriptions were evaluated and there were 1,238 interventions. The classifications and quantities of interventions were related to route of administration $105(8.48 \%)$, frequency 73 (5.89\%), dosage 431 (35\%), renal function 14 (1.13\%), compatibility $50(4 \%)$, dilution $121(9.77 \%)$, legibility $39(3.15 \%)$, pharmacovigilance $7(0.56 \%)$, adverse reaction to medications (ARM) $7(0.56 \%)$, allergies $35(2.82 \%)$, time of infusion $76(6.13 \%)$, indication 52 $(4.20 \%)$, medication reconciliation $2(0.16 \%)$, enteral administration of medications $38(3 \%)$, scheduling $7(0.56 \%)$, specific protocol for anticoagulants 44 $(3.55 \%)$ and specific protocol for hypoglycemic agents $42(3.99 \%)$.

Figure 1 illustrates the classification and number of pharmaceutical interventions performed.

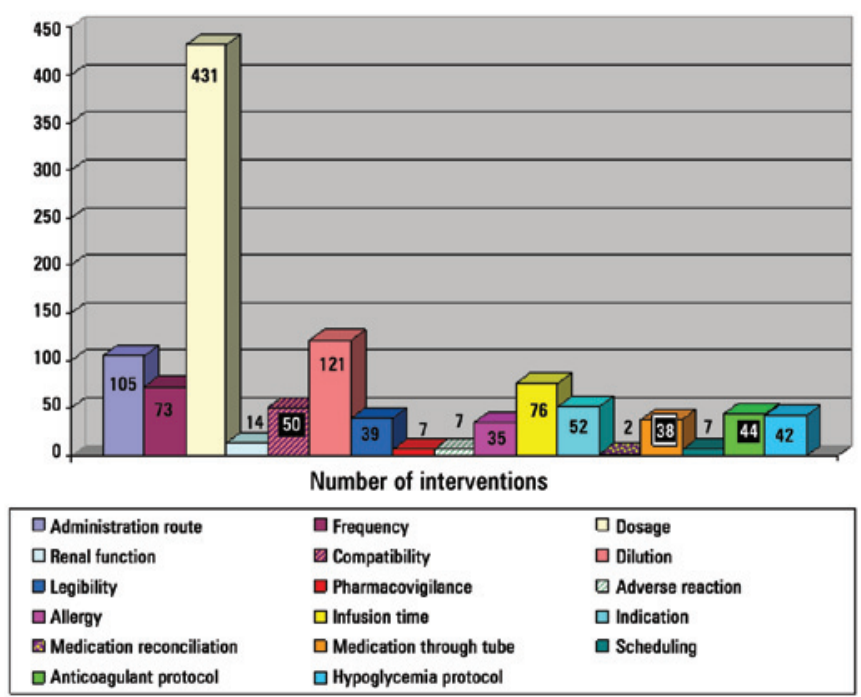

Figure 1. General classification of pharmaceutical interventions performed in the Emergency Department

Chart 1. Description of pharmaceutical interventions in the Emergency Department

\begin{tabular}{|c|c|c|c|}
\hline Classification of the intervention & Description of case & Pharmaceutical intervention & Resolution \\
\hline \multirow[t]{3}{*}{ Not usual dose } & $\begin{array}{l}\text { Prescribed for } 5 \text {-day-old newborn, } 2,900 \mathrm{~kg} \text { : } \\
\text { cefotaxime } 50 \mathrm{mg} \text { IV every } 8 \text { hours }\end{array}$ & $\begin{array}{l}\text { Dose of cefotaxime lower that recommended } \\
\text { in literature ( } 100 \text { to } 150 \mathrm{mg} / \mathrm{kg} / \text { day) divided } \\
\text { into every } 8 \text { to } 12 \text { hours }\end{array}$ & $\begin{array}{l}\text { Changed to: cefotaxime } 150 \mathrm{mg} \text { IV } \\
\text { every } 12 \text { hours }\end{array}$ \\
\hline & $\begin{array}{l}\text { Prescribed for 4-month-old infant, } 7 \text { kg: } \\
\text { Clavulin }{ }^{\circledR} \text { BD } 400 \text { mg/5 mL } 3 \text { mL PO now }\end{array}$ & Dose indicated for $7-\mathrm{kg}$ child: 1.1 to $2.0 \mathrm{~mL}$ & $\begin{array}{l}\text { Changed to: Clavulin }{ }^{\circledast} \text { BD } \\
400 \mathrm{mg} / \mathrm{mL} 2 \mathrm{~mL} \text { PO now }\end{array}$ \\
\hline & $\begin{array}{l}\text { Prescribed for one elderly patient: } \\
\text { clarithromycin } 500 \mathrm{mg} \text { PO every } 12 \text { hours, } \\
\text { patient with } \mathrm{Clcr}=178 \mathrm{~mL} / \mathrm{min}\end{array}$ & $\begin{array}{l}\text { Recommended adjustment of the dose of } \\
\text { clarithromycin for patients with } \\
\mathrm{Clcr}<30 \mathrm{~mL} / \mathrm{min} \text { : half the dose or } \\
\text { double the administration interval }\end{array}$ & $\begin{array}{l}\text { Changed to: clarithromycin } \\
250 \text { mg PO every } 12 \text { hours }\end{array}$ \\
\hline Inadequate dilution & $\begin{array}{l}\text { Prescribed polymyxin B } 500.000 \mathrm{IU}+ \\
\text { NS } 250 \mathrm{~mL} \text { IV every } 12 \text { hours }\end{array}$ & $\begin{array}{l}\text { Recommended dissolution of polymyxin B } \\
\text { sulfate } 500.000 \mathrm{IU} \text { in } 300 \text { to } 500 \mathrm{~mL} \text { of } 5 \% \\
\text { dextrose in water for continuous intravenous } \\
\text { infusion }\end{array}$ & $\begin{array}{l}\text { Changed to: polymyxin B } 500.000 \mathrm{IU}+ \\
\text { 5\% GS } 300 \mathrm{~mL} \text { IV every } 12 \text { hours }\end{array}$ \\
\hline Not usual route of administration & $\begin{array}{l}\text { Prescribed for } 11 \text {-year-old child weighing } 37 \text { kg: } \\
\text { NS } 100 \mathrm{~mL}+\text { Humalog } \text { insulin (lispro insulin) }_{100 \text { IU IV } 3.7 \text { IU/h (0.1 IU/kg/hour) }}\end{array}$ & $\begin{array}{l}\text { Humalog }{ }^{\circledast} \text { insulin has no indication } \\
\text { for intravenous administration; } \\
\text { give subcutaneously only }\end{array}$ & $\begin{array}{l}\text { Changed to: NS } 100 \mathrm{~mL}+\text { Humulin R } \\
\text { insulin (regular insulin) } 100 \mathrm{IU} \text { IV } \\
3.7 \mathrm{IU} / \mathrm{h} \text { (0.1 IU/kg/hour) }\end{array}$ \\
\hline Inadequate infusion time & $\begin{array}{l}\text { Prescribed: hypertonic solution ( } \mathrm{NaCl} 3 \% \text { ): } \\
\text { NS } 450 \mathrm{~mL}+\mathrm{NaCl} 20 \% 50 \mathrm{~mL} \text { IV in } 1 \text { hour }\end{array}$ & $\begin{array}{l}\text { Recommendation that for the administration } \\
\text { of hypertonic solutions ( } 3 \text { or } 5 \% \text { ), the maximal } \\
\text { velocity should not exceed } 100 \mathrm{~mL} / \text { hour }\end{array}$ & $\begin{array}{l}\text { Change of time of infusion of } \\
\text { NS } 450 \mathrm{~mL}+\mathrm{NaCl} 20 \% \mathrm{IV} \text { in } 1 \text { hour } \\
\text { to infusion in } 5 \text { hours }\end{array}$ \\
\hline Inadequate frequency of administration & $\begin{array}{l}\text { Prescribed: Fentanyl (Durogesic }{ }^{\circledR} \text { ) } \\
25 \text { mcg TD once a day }\end{array}$ & $\begin{array}{l}\text { Recommendation that Durogesic }{ }^{\circledR} \text { TD } \\
\text { be changed every } 72 \text { hours }\end{array}$ & $\begin{array}{l}\text { Changed to: Fentanyl (Durogesic }{ }^{\circledR} \text { ) } \\
25 \text { mcg TD once every } 72 \text { hours }\end{array}$ \\
\hline
\end{tabular}

IV: intravenous; PO: orally; Clcr: creatinine clearance; NS: normal saline; TD: transdermal; GS: glucose solution. 
Seventeen types of interventions were classified. We selected the five that showed greatest incidence and that represent the majority of the cases: dosage (431), dilution (121), route of administration (105), time of infusion (76) and frequency (73). The descriptions of these five types of interventions are on chart 1.

\section{DISCUSSION}

This study demonstrates that pharmaceutical intervention can positively contribute to the reduction of problems related to medications (PRMs). The benefit of clinical pharmacist involvement in patient care was observed based on the number of interventions that occurred. Dose-related interventions represent $35 \%$ of the total number of interventions performed, for example, medications prescribed without the dosage, dosage higher or lower than usual, wrong dosage presentation or unavailable on the market, indicating a great impact on the prevention of medication errors. A similar study conducted at the Detroit Receiving Hospital, in Detroit, Michigan, points out two major classes of pharmaceutical interventions that consist in the appropriate selection of medications and in the most appropriate dosage of the medication prescribed ${ }^{(10)}$.

On the other hand, interventions classified in medication reconciliation represent the smallest number: only two interventions of the 1238 performed. This number may be justified considering that at HIAE there is a policy of medication reconciliation that may be performed within 48 hours after hospital admission, as it is not a priority in the Emergency Department.

Interventions classified as allergies are very important, due to the high risk of administration of medications prescribed to which the patient reports having an allergy, as well as in the case of allergic crossreactions. Despite the number of interventions not being as significant as others that showed a higher incidence, the fact of avoiding the inadvertent use in cases of allergies is extremely important for the safety of the patient. The clinical pharmacists should be alert regarding allergies notified by the patient and recording the said allergy on the medical prescription. Problems with information about allergies have been reported in literature, and some studies suggest that the involvement of the pharmacist is fundamental for its identification ${ }^{(11)}$.

Frequency for administration of medications represents a large part of the interventions performed; the clinical pharmacist present in the ED can identify any irregularity and if the frequency of dosing is not appropriate, that is, if it is higher or lower than what is recommended, or if information is not provided on the medical prescription he/she is responsible for contacting the prescribing physician for confirmation and warning as to the correct frequency of the medication, avoiding administration at wrong intervals.

The clinical pharmacist should be integrated with the interdisciplinary team, accompanying daily the work carried out and seeking to add his/her pharmaceutical knowledge as an assistant. It is also possible to verify the promotion of patient safety, since the majority of medication errors occur during the prescription phase and in the process of administration of the medication; thus, the pharmacist has a greater influence for appropriate prescription and use of the medication $^{(12)}$.

The ED offers a wide range of services, activities, and opportunities for the clinical pharmacist's participation. One should consider the need for services for the management of drug therapy, evaluation, and clarification as to allergy to medications, evaluation of the prescription as to medicinal interaction, and preparation of reports on pharmaceutical interventions related to errors of medication and adverse reactions to drugs ${ }^{(13)}$. These activities demonstrate the role of the clinical pharmacist in the ED and are directly related to the interventions described in this study.

One limitation to be considered is that the clinical pharmacist has not been present in the ED fulltime. Data demonstrate the importance of the presence of the professional in the ED in order to assure total patient safety and future participation of the clinical pharmacist in the Emergency Department.

The role of the pharmacist in the ED is rapidly evolving. Currently, it is estimated that less than $5 \%$ of the emergency departments have a clinical pharmacist; the expectation, however, is that there be an increase over the next few years. The presence of the clinical pharmacist in the ED will also be needed due to increased requirements of the Joint Commission related to the revision of the medical prescription by the pharmacist ${ }^{(14)}$. One study on the establishment of the Clinical Pharmacy Service in the ED suggests that the pharmacist may improve the fulfillment of safety goals for the patient as per the Joint International Commission, besides promoting safety and effective care to the patient, avoiding medication errors and offering support to healthcare professional by means of information on medications ${ }^{(15)}$.

Pharmaceutical interventions generate direct benefits for the patient and for the interdisciplinary team, besides affording an increment of the quality of patient treatment. The ED is a dynamic sector and 
the interventions performed by the clinical pharmacist may bring better results, thus guaranteeing safety in drug therapy.

\section{CONCLUSION}

The study allowed the demonstration of the importance of the clinical pharmacist's role in an ED. Using the classification and number of interventions performed, it was possible to observe that the Clinical Pharmacy Service had a great impact on increased safety for the patient and prevention of adverse events.

\section{REFERENCES}

1. Martins HS, Damasceno MCT, Awada SB.. Pronto-socorro - diagnóstico e tratamento em emergências. 2a ed. rev. e ampl. São Paulo: Manole, 2008.

2. Ling JM, Mike LA, Rubin J, Abraham P, Howe A, Patka J, et al. Documentation of pharmacist interventions in the emergency department. Am J Health Syst Pharm. 2005;62(17):1793-7.

3. Fairbanks RJ, Hildebrand JM, Kolstee KE, Schneider SM, Shah MN. Medical and nursing staff highly value clinical pharmacists in the emergency department. Emerg Med J. 2007;24(10):716-9.

4. Cohen V, Jellinek SP, Hatch A, Motov S. Effect of clinical pharmacists on care in the emergency department: a systematic review. Am J Health Syst Pharm. 2009;66(15):1353-61. Review.
5. Flowers PW. Use of clinical pharmacists in academic emergency departments. Am J Health Syst Pharm. 2009;66(6):576-9.

6. Rothschild JM, Churchil W, Erickson A, Munz K, Schuur JD, Salzberg CA, et al. Medication errors recovered by emergency department pharmacists. Ann Emerg Med. 2010;55(6):513-21.

7. Carter MK, Allin DM, Scott LA, Grauer D. Pharmacist-acquired medication histories in a university hospital emergency department. Am J Health Syst Pharm. 2006;63(24):2500-3.

8. Brown JN, Barnes CL, Beasley B, Cisneros R, Pound M, Herring C. Effect of pharmacists on medication errors in an emergency department. Am J Health Syst Pharm. 2008;65(4):330-3.

9. Case LL, Paparella S. Safety Benefits of clinical pharmacist in emergency department. J Emerg Nurs. 2007;33(6):564-6.

10. Lada P, Delgado GJ Jr. Documentation of pharmacists' interventions in emergency department and associated cost avoidance. Am J Health Syst Pharm. 2007;64(1):63-8.

11. Barley KB, Savitz LA, Maddalone T, Stoner SE, Hunt JS, Wells R. Evaluation of patient care interventions and recommendations by a transitional care pharmacist. Ther Clin Risk Manag. 2007;3(4):695-703.

12. Patanwala AE, Warholak TL, Sanders AB, Erstad AL. A prospective observational study of medication errors in tertiary care emergency department. Ann Emerg Med. 2010;55(6):522-6.

13. American Society of Health-System Pharmacists. ASHP statement on pharmacy services to the emergency department [Internet]. [cited 2012 Jan 4]. Available from: http://www.ashp.org/s_ashp/docs/files/BP_Pharm_Role_ED-D11.pdf

14. Wymore ES, Casanova TJ, Broekemeier RL, Martin JK Jr. Clinical pharmacists's daily role in the emergency department of a community hospital. Am J Health Syst Pharm. 2008;65(5):395-6, 398-9.

15. Hong AL, Brozick A, Lam S, Parris M, Paine M, Flowers PW. Pharmacist implementation in the emergency department. Ann Emerg Med. 2009; 54(3):S78-9. 